\title{
Evaluation of Open Innovation with R\&D Alliances for Breakthrough Technologies in the Energy Sector
}

\author{
Stephan Hess $^{1} \&$ Roland Y. Siegwart ${ }^{2}$ \\ ${ }^{1}$ Alstom Power, Baden, Switzerland \\ ${ }^{2}$ Swiss Federal Institute of Technology, Zuerich, Switzerland \\ Correspondence: Stephan Hess, Alstom Power Switzerland. Tel: 41-56-205-1399. Fax: 41-56-205-4757. E-mail: \\ stephan.hess@alstom.com
}

Received: May 27, 2014

Accepted: June 17, 2014

Online Published: June 19, 2014

doi:10.5430/bmr.v3n2p123

URL: http://dx.doi.org/10.5430/bmr.v3n2p123

\begin{abstract}
In the energy industry, a time of dynamic innovation and uncertainties drives R\&D incumbents to extend their technology screening process to the early technology lifecycle. Many early breakthrough technology innovations stem from academia and are developed by academic spin-offs. In these situations an incumbent's future technology organization (FTO), focused on open innovation, needs to expand its evaluation and development capabilities towards R\&D alliances with academic technology spin-offs.

In the light of the open innovation and real option frameworks this study analyzes $R \& D$ projects using the real options analysis (ROA) and discusses the critical decision of whether to develop technology internally or externally. It explores R\&D alliances between academic spin-offs and a large power industry player and investigates the concept and role of a FTO in the open innovation process. A model will be introduced to operationalize the FTO concept and practically evaluate the risk of open innovation with $R \& D$ alliances for breakthrough technologies. Contrary to the common view that risks increase when open innovation is applied along with external development of a breakthrough technology in R\&D alliances, the present study shows that the risks and uncertainties can be mitigated and controlled when applying ROA and the FTO model.
\end{abstract}

Keywords: Research \& Development, Alliances, Spin-offs, Innovation management, Breakthrough technologies

JEL Classification Codes; O31, O32, O33, L2, L3, L64, L97

\section{Introduction}

Large enterprises in the power industry are currently challenged by a time of high innovation dynamics with many early-lifecycle technologies evolving and competing (Schilling \& Esmundo, 2009; Mowery et al., 2010). Aggressive demands for new power technologies (e.g., in renewable energy, energy storage, or efficiency increase with new high temperature materials) require breakthrough innovation. Firms in this industry need to actively increase their technology and their environmental scanning behavior toward the early technology lifecycle. Unfortunately large incumbent firms often struggle in an environment of rapid change and rarely introduce breakthrough technology innovations (Arvanitis et al., 2005; Gilbert, 2005; Harhoff et al., 1996; Polt et al., 2001; Tornatzky \& Fleischer, 1990; Utterback \& Abernathy, 1975). This can be seen within existing R\&D departments that are geared to developing and increasing the efficiency of current technology (Cohen \& Levinthal, 1989). Therefore research and development departments are often risk averse and respond inadequately to breakthrough innovation (Adams, 2005; Ahuja \& Lampert, 2001; Henderson, 1993; Kanter, 1985).

The gatekeeper (technology scouts or listening posts as Gassmann \& Gaso (2004) defined), are an incumbent's R\&D established peripheral element. As such, their mission is to identify trends and opportunities for external knowledge sourcing with a focus on their disruptive potential (Rohrbeck, 2007). Because the risk profile of open innovation projects is high due to the early stage of the technology lifecycle, such peripheral foresight (Reger, 2010) activity often ends at the interface to the incumbents R\&D organization (Christensen, 2003). For technology breakthrough development with external R\&D partners incumbents need to manage an especially adapted technology development process (Vanhaverbeke et al., 2008).

With the introduction of the open innovation paradigm (Chesbrough, 2003), it has been suggested that large incumbents should consider scanning a wider range of externally available innovation rather than concentrating on 
centralized internal R\&D innovations. The advantage of open innovation is that it gives established companies early access to information about new technologies and allows them to tap into externally developed, upstream technologies (Chesbrough et al., 2006). In a literature analysis on open innovation Dahlander \& Gann (2010) distinguish inbound and outbound open innovation processes, were inbound open innovation contains sourcing and acquiring processes. Because many early lifecycle technologies stem from academia, R\&D alliances between industry and academia or academic technology spin-offs are a feasible application for industries inbound open innovation (Dahlander \& Gann, 2010) and it seems to be of interest to investigate new technology development models (Hess et al. 2013; Hess \& Siegwart 2013, Stankiewicz, 1994; Fontes, 2005; Papart, 2004). The literature in this field claims that large centralized R\&D labs are becoming obsolete in many industries (Chesbrough, 2003) or need to "open up" the R\&D and establish coupled open innovation processes through alliances, cooperation or joint ventures (Enkel et al., 2009). However, still many R\&D organizations within industry consider the open innovation approach with external R\&D alliances a risk-laden activity (Vanhaverbeke et al., 2008).

The theory of real options has been derived from financial option contracts (Black \& Scholes, 1973) to evaluate the value of flexibility or options for real assets (McDonald \& Siegel, 1985). In applying the ROA (Yeo \& Qiu, 2002; Copeland \& Antikarov, 2001; Leiblein, 2003; Guthrie, 2009) to open innovation, new capabilities are proposed to support the decision between an internal or external R\&D project (Vanhaverbeke et al., 2008). In a biopharmaceutical study (Lo Nigro et al.,2013) it has been proposed to evaluate R\&D projects with ROA for in house development or in an alliance open innovation model. An overview of ROA applications and a model to evaluate R\&D projects has been suggested by Perlitz et al. (1999) and the value of management flexibility with a discussion of different real options in technology investments has been introduced by Yeo \& Qiu (2002). It has been shown that the effect of real options on technological innovation moderated by environmental uncertainty is significant (Verdu et al., 2012). Furthermore it has been found that “...Managers applying real options reasoning in their firms perceive the right to make other decisions later that will benefit them and thus aid in technology innovation, especially in situations of environmental uncertainty, defined as the lack of clarity of changes in the environment..." (Verdu et al., p. 586, 2012) and that “...real option reasoning improves flexibility..."(Verdu et al., p. $586,2012)$. However in an environment of uncertainty "... managers find it costly to negotiate and write complete contracts that fully describe each party's responsibility and rights for all future contingencies that could conceivably arise during a transaction.” (Leiblein, p.940, 2003). Still Adner \& Levinthal (2002) argue that ROA in technology investments should be exogenous from the investor and R\&D managers do not perform separate from the success of their project.

Academic technology spin-offs with their agility and speed are considered straightforwardly successful regarding breakthrough innovation (Andersson \& Lööf, 2011; Christensen, 2003), counteracted by their vulnerability caused by economic and market barriers (Marmer et al., 2011). Focusing on the open innovation with coupled processes Hess \& Siegwart (2013) described the development of technology alliances for breakthrough innovation and proposed using the term "R\&D Venture", which they define as an R\&D alliance between an established industry and academic technology spin-offs. Technology spin-offs and alliances in this study are described in Hess \& Siegwart (2013).

The present paper proposes applying the model of a future technology organization, which should build additional to technology foresight and scanning, new capabilities using risk evaluation processes and methods to control external R\&D alliances with technology spin-offs as R\&D Ventures. Consequently the research question follows as: How do large corporate organizations in an environment of uncertainty evaluate open innovation and incubate new technologies with reduced risk exposure in technology development with R\&D Ventures?

\section{Methodology}

A case study with an industry partner was conducted investigating the buildup of a FTO model with open innovation capabilities. The team investigated and applied the ROA on one internal R\&D project and five open innovation cases: three existing R\&D Ventures, an external academic spin-off in ceramics, and the opportunity to build an R\&D Venture in energy storage. The aim was to develop an open innovation process and organizational capabilities in a FTO model to engender continuous innovation with ROA and an R\&D Venture approach.

For the research the authors joined the FTO team and the different R\&D Ventures and took part in many workshops, met the development teams on their R\&D projects and had access to all relevant managers of the industry technology organization including CTO, R\&D management, open innovation management, chief engineers, and the management of the FTO and the R\&D Ventures. In all cases, the investigation began with semi-structured interviews with people in relevant management positions. The data were obtained from notes taken during interviews and workshops (Flick, 2002; Miles \& Huberman, 1994) and from detailed documentation about technology assessments, business case 
evaluations, and archival documents regarding the spin-offs or alliance agreements. These findings have been discussed and analyzed along decision trees of a ROA.

The case study method was selected, as it allows for the detailed investigation and analysis of a management problem (Eisenhardt \& Graebner, 2007; Patton, 2002). This study focuses on understanding problems and patterns, conceptualization and on building a model, rather than on the testing or validation of hypotheses (Yin, 2009).

The base data of the ROA reflect the status of the R\&D projects or ventures; however, only representative data are presented in the results in order to keep information confidential. The names of inventors and spin-offs have been changed to protect the companies' identities.

\section{Case Studies}

The FTO is part of a wider R\&D and technology organization, which includes material laboratories, testing centers, and research laboratories. The FTO focuses on usual technology foresight with technology screening, scouting, and evaluation. The FTO is well connected to the R\&D organization's expert's network and as a technology gatekeeper; the FTO is also closely connected to global academic networks within universities and research labs. The FTO's capabilities rely on highly educated technology and research employees and a research and testing laboratory infrastructure. The FTO technology experts follow new technology opportunities; assess technical feasibility and strategic relevance. Technologies of interest will only be pursued, however, when a business unit with relevant R\&D capabilities is willing to further develop, fund, and adopt the technology in its portfolio. However this process is often difficult because of the early lifecycle status of the evaluated technologies and the embedded financial risks of development and marketing. Therefore the FTO aims to develop capabilities to run a continuous open innovation process for a joint breakthrough technology development with alliance technology spin-offs such as R\&D Ventures.

Table 1 shows the existing and potential R\&D Ventures evaluated by FTO.

Table 1. R\&D Ventures investigated by FTO

\begin{tabular}{|c|c|c|c|c|c|}
\hline Company & Alpha & Beta & Gamma & Delta & Epsilon \\
\hline Industry & - Robotics & - Machines & $\begin{array}{r}\text { - Electronics } \\
\text { and Sensors }\end{array}$ & $\begin{array}{l}\text { - Materials \& } \\
\text { Process Technology }\end{array}$ & - Machines \\
\hline $\begin{array}{l}\text { Technology } \\
\text { Leve1 }\end{array}$ & $\begin{array}{l}\text { - Industrialisation } \\
\text { / Scaling }\end{array}$ & $\begin{array}{l}\text { - Industrialisation } \\
\text { / Scaling }\end{array}$ & $\begin{array}{l}\text { - Industrialisation } \\
\text { / Scaling }\end{array}$ & - Demonstrator & $\begin{array}{l}\text { - Invention and } \\
\text { Business Case }\end{array}$ \\
\hline Technology & $\begin{array}{l}\text { - Industrial } \\
\text { Inspection } \\
\text { Robotics }\end{array}$ & $\begin{array}{l}\text { - Water jet } \\
\text { Cleaning \& } \\
\text { Cutting } \\
\text { Technology }\end{array}$ & $\begin{array}{l}\text { - Sensor \& Non } \\
\text { Destructive } \\
\text { Testing } \\
\text { Technology }\end{array}$ & $\begin{array}{l}\text { - Ceramic Process } \\
\text { Technology \& } \\
\text { Engineering }\end{array}$ & - Energy Storage \\
\hline Foundation & $\begin{array}{l}\text { - Founded in } 2006 \\
\text { as an } \\
\text { Alliance Start-Up }\end{array}$ & $\begin{array}{l}\text { - Founded in } 2007 \text { as } \\
\text { Spin 0ff and turned } \\
\text { into an Alliance } \\
\text { Start-Up in } 2008\end{array}$ & $\begin{array}{l}\text { - Founded in } 2009 \\
\text { by Management; } \\
\text { Alliance Start- } \\
\text { Up in } 2012\end{array}$ & $\begin{array}{l}\text { - } 2007 \text { Alliance } \\
\text { Negotiation since } \\
2011\end{array}$ & - Not yet founded \\
\hline Ownership & $\begin{array}{l}\text { - Management } 25 \% \\
\text { - Academia 24\% } \\
\text { - Industry Partner 51\% }\end{array}$ & $\begin{array}{l}\text { - Management } 41 \% \\
\text { - Academia } 10 \% \\
\text { - SMI-Partner } 19 \% \\
\text { - Industry Partner } 30 \%\end{array}$ & $\begin{array}{l}\text { - Management } 57 \% \\
\text { - Academia } 43 \%\end{array}$ & $\begin{array}{l}\text { - Mgmt. } 90 \% \\
\text { - Academia } 10 \%\end{array}$ & - Planning Phase \\
\hline Employees & $\cdot 20$ & $\cdot 6$ & • 4 & $\cdot 7$ & $\cdot-$ \\
\hline Patents & $\cdot 6$ & $\cdot 6$ & $\cdot 4$ & $\cdot 1$ & $\cdot 1$ \\
\hline
\end{tabular}

Alpha was founded in 2006 as an R\&D Venture in the inspection robotics industry between an established power generation service company and an academic partner. Alpha's purpose is to adopt the latest breakthrough technologies in the academic sphere and find the fastest way to reach the demonstrator phase.

Beta, which is active in the manufacturing industry as a leading water jet cutting and cleaning product and service provider, was founded as a alliance between an academic partner and an small and medium enterprises (SME) in the regional manufacturing industry. Their product application significantly reduces the speed of overhauling and maintaining power plants and increasing their efficiency. 
Founded in 2009, Gamma is owned by academic founders whose goal was to build a market position in the sensor market for non-destructive testing. Gamma is currently developing new technologies for miniaturizing sensor products.

Delta is an academic spin-off of ceramic foam technology. The general aim of power generation is to improve the efficiency of the thermal process, which leads to continuous temperature increases in the thermal cycles of (e.g., boilers, gas turbines, and solar power plants). New material technology innovations are of significant interest for the industry.

Epsilon is an energy storage project opportunity. An internal R\&D project dealing with energy storage will usually be of substantial size and long-term duration; therefore, it bears significant technological and market risks. With the R\&D Venture approach, FTO built an external R\&D Venture business case with the venture target of industrializing the first demonstrator and approaching the domestic low-size energy storage market. In the following chapter the evaluation of internal $R \& D$ projects versus an open innovation approach with $R \& D$ Ventures will be discussed.

\section{Internal versus External R\&D Projects: A Critical Decision}

$R \& D$ project decisions on external development projects are critical to a firm. This section compares the open innovation $R \& D$ Venture approach with an internal R\&D project. Figure 1 illustrates a simulation of an internal $R \& D$ project for inspection robotics compared with the R\&D Venture Alpha. The same R\&D performance in time, cost, and delivery has been assumed, and industry partner paybacks for delivering R\&D results have been simulated for both projects and are assumed to be the same.

As shown in Figure 1, an R\&D project and an R\&D Venture are evaluated using an R\&D cost breakdown and anticipated cash flows over time to calculate the projects expected benefits. On the right-hand side of Figure 1, the value accumulation over time shows that an internal $R \& D$ project loses its value if it is abandoned. For the $R \& D$ Venture, the value of the project remains even if the project is abandoned; in this case, the value of R\&D investments remains in the firm and the technology capability remains stable. The venture could then assume a role such as a technology supplier or could be sold externally. Thus, because R\&D Ventures conserve value and technology capabilities, they should be evaluated differently.

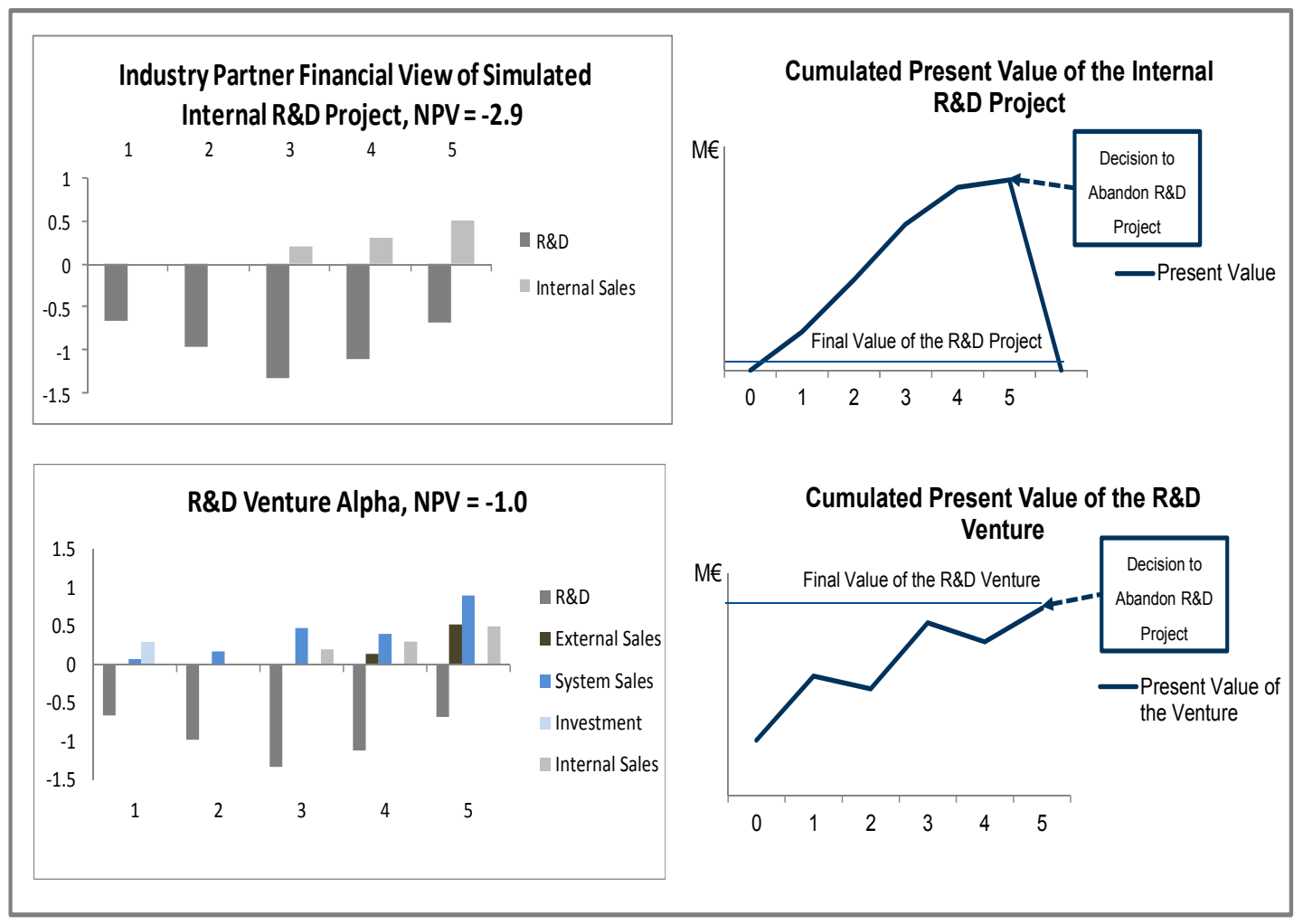

Figure 1. Project calculation for a simulated inspection robotics scope as an internal R\&D project and the R\&D Venture Alpha 
The most commonly used method to evaluate $R \& D$ investments with the industry partner is the net present value (NPV) method. The NPV method does not account for any flexibility that R\&D might have when developing the project. Given the high level of uncertainty $R \& D$ teams encounter when investigating early breakthrough technologies beyond their technology experience or evaluating potential $R \& D$ projects, flexibility in decision making and timing is a central risk-mitigation factor. Flexibility is highly relevant when evaluating an opportunity for open innovation with external R\&D Ventures and causes the NPV method to undervalue investments considerably. In particular, the NPV method does not consider the option of (1) abandoning an R\&D project; (2) expanding, contracting, or delaying the project; or (3) choosing to learn in the project.

Figure 2 details an internal R\&D project process compared with the options possible with an R\&D Venture.

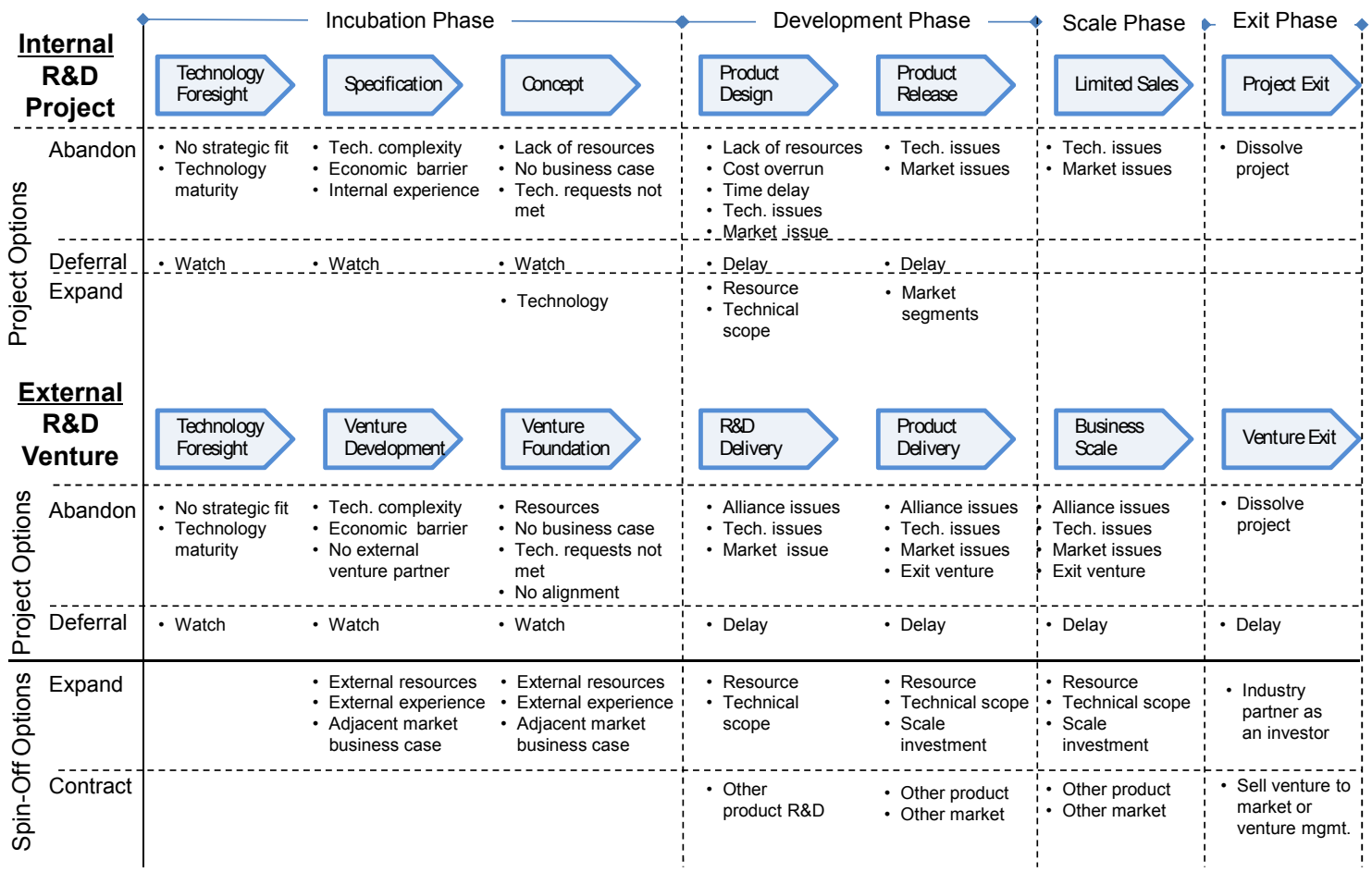

Figure 2. Flexibility of an internal $R \& D$ project process versus an open innovation $R \& D$ Venture process

In the following sections, the options are discussed along the incubation, development, scaling, and exit phases for both processes of developing a breakthrough technology internally or externally. The incubation phase for both processes starts with technology foresight and the options to abandon or defer the project. If R\&D has a technological interest, technology complexity and economic barriers must be evaluated as the main drivers of the decision to abandon or defer the project. In an R\&D Venture, external resources and capabilities are called upon to assess the project, leading to an additional option to expand the venture to consider the business case for external markets.

In the process step, the option to abandon is valid for both processes if the technology requests or economic requirements are not met. In the incubation phase, the options for an R\&D Venture are advantageous because of additional expansion flexibility is available with external partners and markets.

After the development phase begins, resources are set and, to a certain extent, constrained. Cost overruns, time delays, and technical and market issues can all lead to abandoning projects. The R\&D Venture has additional flexibility in the option to compensate time and market problems by deferring its focus to external market product development. The deferral option to delay for internal $R \& D$ projects is very cost-intensive and carries the risk of losing technology expertise. However, for R\&D Ventures with the flexibility to switch to other market activities, delaying a project (e.g., waiting for a market window opening), is feasible.

Once the product-release gate has been achieved, an R\&D project will only be abandoned for technical or market issues. The R\&D Venture still bears the additional alliance risk, but because the venture possesses sellable products at this stage, its value is secure, and it can be sold. This opens either a valid contract or an abandon option. R\&D Venture performance can also be increased through a first scaling of the business (e.g., in marketing or production for external markets). The development phase favors option opportunities for R\&D Ventures and adds flexibility, particularly in delaying the ramp-up of development costs. This consequently reduces the risk of failure. 
Scaling internal $R \& D$ projects with limited or unlimited product sales bears the risk of technical and market issues; at this late stage, the only flexibility is the costly option of abandoning the project. For R\&D Ventures, on the other hand, all other options (delaying the project by refocusing on external markets; expanding and scaling with additional resources; or exiting the R\&D Venture for a market price) are still valid and allow flexibility in managing the process.

The exit phase allows the internal R\&D project to be abandoned or dissolved, and in some cases, acquired materials and infrastructure can be valued. For the R\&D Venture, the exit phase offers all the aforementioned options, including delaying or dissolving the project, while changing the venture's role (e.g., into a product supplier) or changing the industry partner's role (from an R\&D partner to an investor). These expansion options offer high flexibility, and ultimately, the venture can be sold to R\&D Venture management or other market players (e.g., venture capitalists or other industries). In the discussion above the R\&D Venture is advantageous as it conserves value and allows for more flexibility particular toward the end of the process when the risk to fail is high. The next chapter investigates the value of the flexibility with ROA.

\section{Value of Flexibility for Internal and External R\&D Projects}

In the present study, the ROA is considered to be the application of financial options to R\&D. In finance an "option" is the right, but not the obligation, to buy or sell an asset at a specific price (strike price) and time. A "call option" is the right to buy an asset, while a "put option" is the opportunity to sell it. The ROA allows the value of the option to be incorporated into the value of the R\&D project (Copeland \& Antikarov, 2001).

A significant source of uncertainty for developing breakthrough technology is the fact that market information in R\&D projects is incomplete. The NPV is the underlying asset or "state variable" that helps determine the project's value and options over time. ROA allows decision trees to be used in evaluating the project in conjunction with the backward induction of a replicating portfolio of the underlying risk-free bonds, assuming the underlying risky asset NPV without flexibility (Guthrie, 2009).

The following discussion reviews the various options that internal R\&D projects and R\&D Ventures offer. The aim of this discussion is not to provide a complete financial model, but to show the different options, how they are evaluated, and their impact on decision making.

Early-stage future technologies have a high level of uncertainty, and R\&D must consider them risky. Because the industry partner has the choice to develop technology internally or externally, he or she needs to estimate the value of the projects, as well as with R\&D Ventures. The financial assumptions concerning the expected cash flows are given as the same for both projects. However, the assumption of the project's value differs if it is sold in the case of abandonment. If an internal $R \& D$ project is stopped and dissolved, the value of the project drops to fixed investments such as materials or the acquired infrastructure. An internal R\&D project cannot be sold, because it consists mainly of the technical expertise of its employees, which can be either distributed to other parts of the internal organization or leave the company. In contrast, an R\&D Venture acquires value and can be sold as an entity for a market price. Even if an R\&D project financed by an industry partner is abandoned, the R\&D Venture maintains its original value.

Table 2 shows the exemplary assumptions for projects using the same financial conditions. The conditions of the options, however, must be addressed separately for both approaches.

Table 2. Assumptions for option discussion between an internal R\&D project and an external R\&D Venture

\begin{tabular}{lll}
\hline Option & Internal R\&D Project & Externall R\&D Venture \\
\hline Expand & $\begin{array}{l}\text { Opportunity to expand the } \\
\text { investment to } 300 \mathrm{k} € \text { and achieve a } \\
10 \% \text { performance increase of the } \\
\text { R\&D project }\end{array}$ & $\begin{array}{l}\text { Opportunity to expand the Investment } \\
\text { to } 300 \mathrm{k} € \text { and achieve an } 30 \% \\
\text { performance increase of the R\&D } \\
\text { Venture }\end{array}$ \\
Contract & $\begin{array}{l}\text { Opportunity to contract the project } \\
\text { for a price of } 450 \mathrm{k} € \text { and sell } \\
\text { project assets of } 10 \%\end{array}$ & $\begin{array}{l}\text { Opportunity to contract the project for a } \\
\text { price of } 450 \text { k } € \text { and sell project assets } \\
\text { of } 10 \%\end{array}$ \\
Abandon & $\begin{array}{l}\text { Opportunity to abandon the project } \\
\text { and sell materials and infrastructure } \\
\text { for a price of } 300 \mathrm{k} €(30 \% \text { of the } \\
\text { origin value })\end{array}$ & $\begin{array}{l}\text { Opportunity to abandon the project } \\
\text { and sell R\&D Venture for a reduced } \\
\text { price of } 700 \mathrm{k} € \text { (60\% of the origin } \\
\text { value) }\end{array}$ \\
\hline
\end{tabular}


Figure 3 shows how both projects can be evaluated based on the backward induction method with the impact of the combined options to expand, contract, and abandon on an internal R\&D project and an external R\&D Venture.

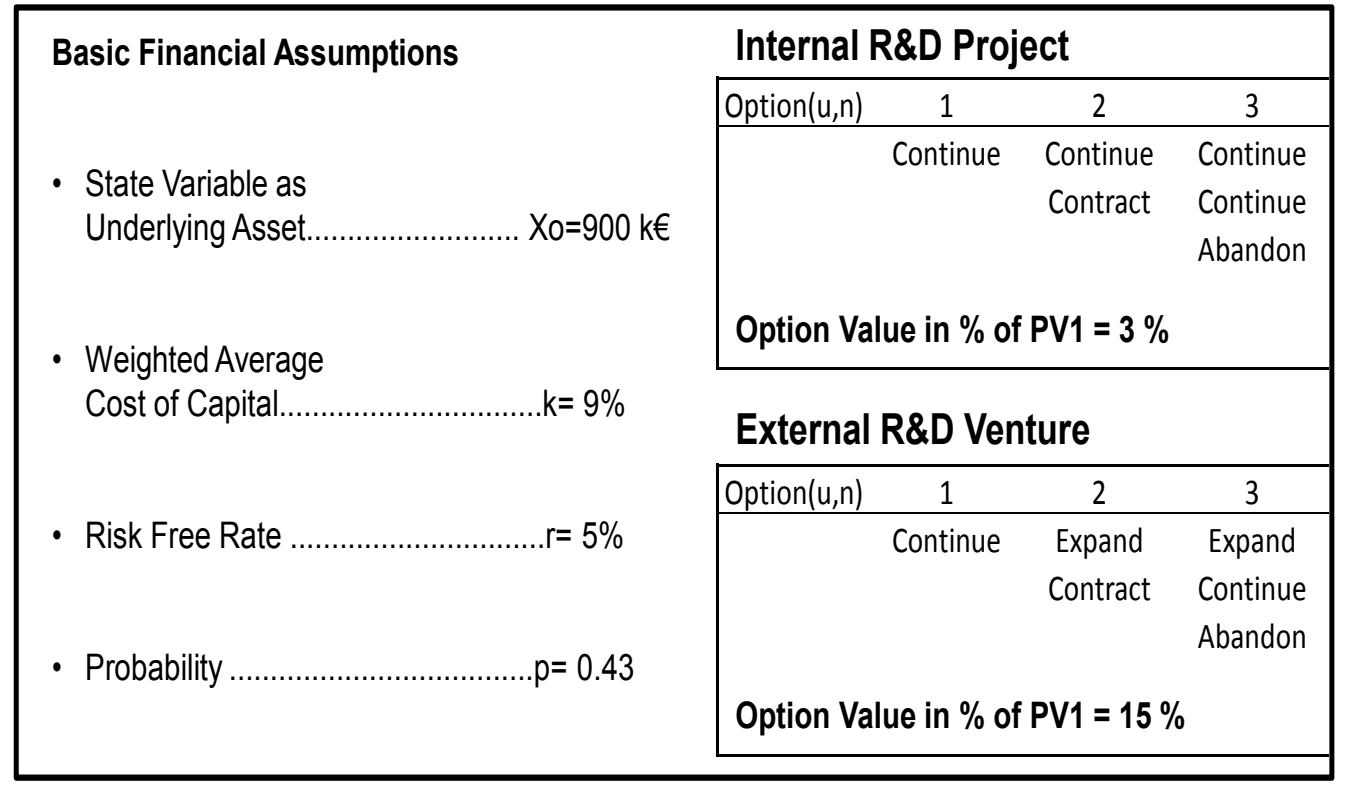

Figure 3. Binominal tree showing the impact of expand, contract and abandon real options in an internal R\&D project and an R\&D Venture (in $\mathrm{k} €$ )

The flexibility of the options on internal R\&D projects is not significant. In the R\&D Venture case, the combined option value is $15 \%$ higher than the value without flexibility.

\section{Findings for the Portfolio of R\&D Ventures}

In order to understand the value of open innovation and the decision process the portfolio of R\&D Ventures ROA will be discussed with decision trees along the technology life-cycle from concept to commercialization. The ROA of the R\&D phase starts by using the decision tree shown in Figure 4 to discuss the risks of a venture. The decision maker has the option either to invest into the R\&D Venture at stage zero or to wait and have the choice of whether to invest. A subsequent or staged investment approach is thus feasible for the investors, which also triggers the industry partner's decision to buy shares in the venture. The responsibility for these option decisions lies with corporate research and the FTO during the early stage to determine the defer option and with the R\&D organization for later R\&D project options. Decision criteria for deferral include the maturity of the technology and the firm's capability to internally or externally execute the R\&D project. For example, a project could be abandoned externally and pursued internally. A market window triggers timing decisions on deferral and abandonment flexibility.

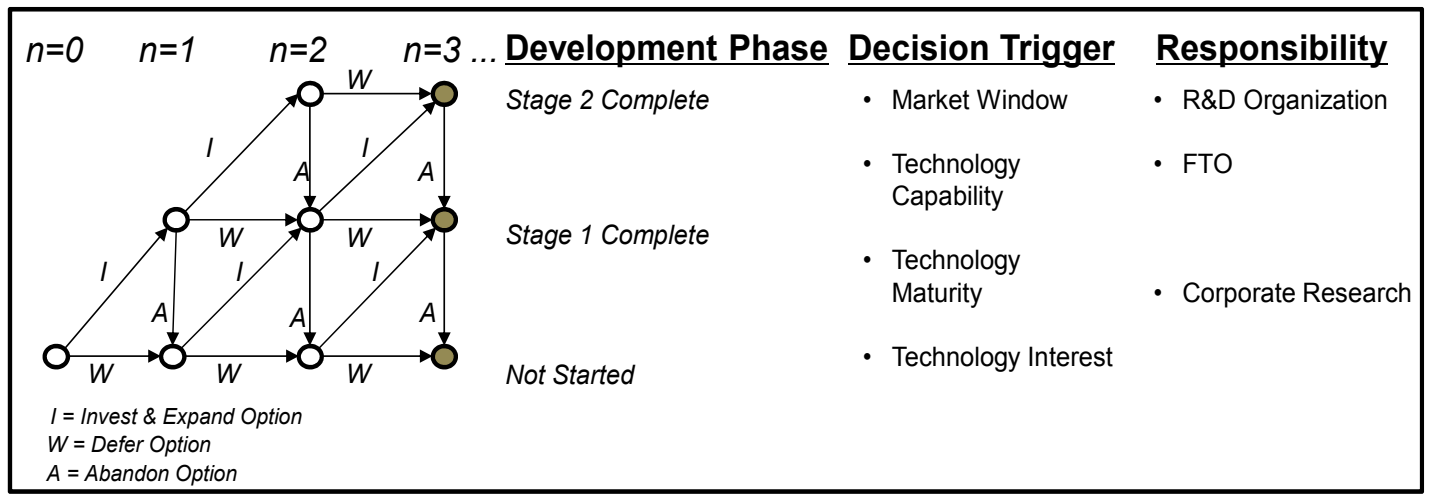

Figure 4. Decision trees for the R\&D Ventures and ROA for the R\&D phase adapted from Guthrie (2009)

After a successful R\&D phase, the scaling phase shown in Figure 5 begins. At this point, the industry partner has the staged decision to either invest further in the product scaling or to wait.

Since the product status of the technology has been achieved, the abandon option is no longer viable. Product success and success in external markets drive the investment decision, which is made by the FTO. 


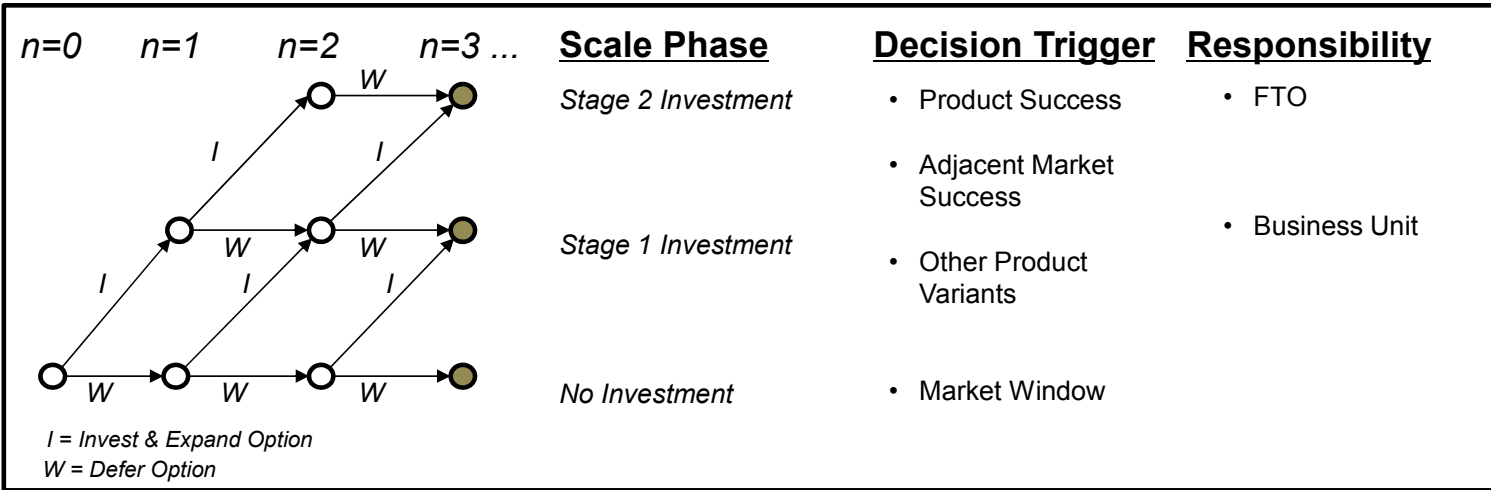

Figure 5. Decision trees for the R\&D Ventures and ROA for the product scale phase adapted from Guthrie (2009)

The option to contract provides flexibility to decide on the future of the R\&D Venture and leads to the exit stage shown in Figure 6. The exit decision, which should be evaluated by FTO and the relevant business unit, depends mainly on the success of products in external markets and on estimating the relevance of technology to the industry partner. Again, the exit can be staged with a contract option; at every node, the industry partner has the option to switch his role in the R\&D Venture into that of a customer, a bond holder, or an investor.

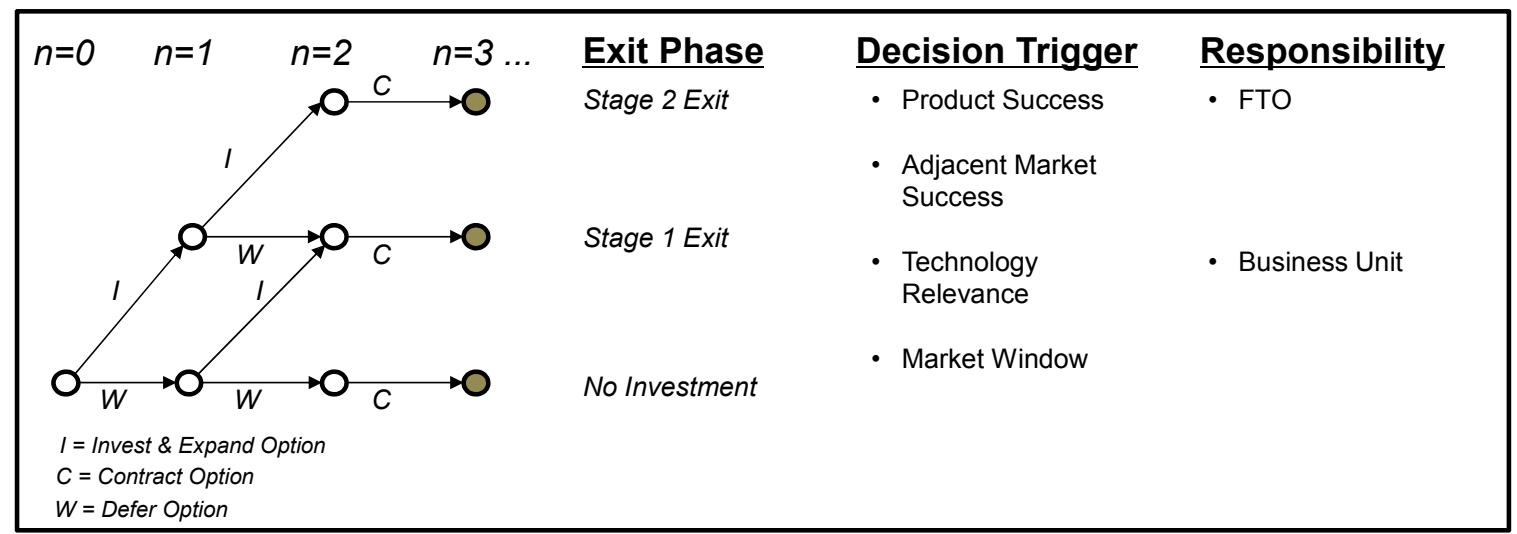

Figure 6. Decision trees for the R\&D Ventures and ROA for the exit phase adapted from Guthrie (2009)

Table 3 displays the assumptions and scenarios made for the R\&D Venture portfolio of the industry partner. The input data are simulated in order to maintain confidentiality. However, based on the current state of each R\&D Venture's business cases, they represent the venture situation and the future business assumptions fairly accurately and are sufficient to discuss the impact range of flexibility in evaluating the venture business.

Companies Alpha, Beta, and Gamma are in the scaling phase and have cumulated value over time; therefore, the contract price is higher than the abandon value. Conversely, because Delta and Epsilon are in the early foundation, incubation, or R\&D stage, the contract value (a viable option for the later development stage) has to be assumed to be lower than the abandon value (a viable option for the early stages).

Table 3. Scenario data for the R\&D Venture option portfolio in [k€]

\begin{tabular}{|c|c|c|c|c|c|}
\hline & Alpha & Beta & Gamma & Delta & Epsilon \\
\hline $\begin{array}{l}\text { State variable (underlying asset) at } \\
\mathrm{t}=0\end{array}$ & 2200 & 1000 & 1000 & 500 & 1000 \\
\hline Contract price & 1500 & 1000 & 750 & 300 & 500 \\
\hline Percentage of selling asset & $50 \%$ & $30 \%$ & $50 \%$ & $30 \%$ & $50 \%$ \\
\hline Expenses to expand & 600 & 300 & 300 & 100 & 1000 \\
\hline $\begin{array}{l}\text { Percentage of increased venture } \\
\text { value }\end{array}$ & $40 \%$ & $20 \%$ & $40 \%$ & $20 \%$ & $50 \%$ \\
\hline Abandon Value & 600 & 600 & 600 & 350 & 600 \\
\hline
\end{tabular}


The percentage of selling an asset reflects the distribution of shares within the venture, whereas the expenses to expand stem from the business cases to invest in developing external markets.

Figure 7 shows the value of flexibility on R\&D Ventures over a 5-year time line and the development phases. The contract option, the combined expand and defer options, and the combined contract, expand, and abandon options have been evaluated for the above scenarios. For each scenario, the flexibility to decide for the option is depicted in a decision tree (showing the right, but not the obligation, to exercise the option). The current option value expressed as a percentage of the initial Present Value of the project (PV1) is presented.

\section{Options}

\begin{tabular}{|c|c|c|c|c|c|c|c|c|c|c|c|c|c|}
\hline \multicolumn{2}{|c|}{ R\&D - Venture } & \multicolumn{4}{|c|}{ Contract } & \multicolumn{4}{|c|}{ Expand, Defer } & \multicolumn{4}{|c|}{$\begin{array}{l}\text { Contract, Expand, Defer, } \\
\text { Abandon }\end{array}$} \\
\hline \multirow{4}{*}{$\begin{array}{l}8 \\
\frac{8}{8} \\
\frac{1}{1} \\
\frac{0}{8} \\
\mathscr{8}\end{array}$} & \multirow[t]{2}{*}{ ALPHA } & $\begin{array}{c}1 \\
\text { contract }\end{array}$ & $\begin{array}{c}2 \\
\text { contract } \\
\text { contract }\end{array}$ & $\begin{array}{c}3 \\
\text { contract } \\
\text { contract } \\
\text { contract }\end{array}$ & $\begin{array}{c}4 \\
- \\
\text { contract } \\
\text { contract } \\
\text { contract }\end{array}$ & $\begin{array}{c}1 \\
\text { expand }\end{array}$ & $\begin{array}{l}2 \\
\text { expand } \\
\text { expand }\end{array}$ & $\begin{array}{c}3 \\
\text { expand } \\
\text { expand } \\
\text { wait }\end{array}$ & $\begin{array}{c}4 \\
\text { expand } \\
\text { expand } \\
\text { expand } \\
\text { wait }\end{array}$ & $\begin{array}{c}1 \\
\text { expand }\end{array}$ & $\begin{array}{c}2 \\
\text { expand } \\
\text { contract }\end{array}$ & $\begin{array}{c}3 \\
\text { expand } \\
\text { contract } \\
\text { contract }\end{array}$ & $\begin{array}{c}4 \\
\text { expand } \\
\text { contract } \\
\text { contract } \\
\text { contract } \\
\end{array}$ \\
\hline & & \multicolumn{4}{|c|}{ Option Value in \% PV1 = $26 \%$} & \multicolumn{4}{|c|}{ Option Value in \% PV 1= $15 \%$} & \multicolumn{4}{|c|}{ Option Value in \% PV1 = $35 \%$} \\
\hline & \multirow[t]{2}{*}{ BETA } & $\begin{array}{c}1 \\
\text { contract }\end{array}$ & $\begin{array}{c}2 \\
\text { contract } \\
\text { contract }\end{array}$ & $\begin{array}{c}3 \\
\text { contract } \\
\text { contract } \\
\text { contract }\end{array}$ & $\begin{array}{c}4 \\
- \\
\text { contract } \\
\text { contract } \\
\text { contract } \\
\end{array}$ & $\begin{array}{c}1 \\
\text { expand }\end{array}$ & $\begin{array}{c}2 \\
\text { expand } \\
\text { wait }\end{array}$ & $\begin{array}{c}3 \\
\text { expand } \\
\text { expand } \\
\text { wait }\end{array}$ & $\begin{array}{c}4 \\
\text { expand } \\
\text { expand } \\
\text { wait } \\
\text { wait } \\
\end{array}$ & $\begin{array}{c}1 \\
\text { expand }\end{array}$ & $\begin{array}{c}2 \\
\text { expand } \\
\text { contract }\end{array}$ & $\begin{array}{c}3 \\
\text { expand } \\
\text { contract } \\
\text { contract }\end{array}$ & $\begin{array}{c}4 \\
\text { expand } \\
\text { expand } \\
\text { contract } \\
\text { contract }\end{array}$ \\
\hline & & & \multicolumn{3}{|c|}{ Option Value in \% PV1 = $48 \%$} & \multicolumn{4}{|c|}{ Option Value in \% PV1 = $3 \%$} & \multicolumn{4}{|c|}{ Option Value in \% PV1 = $40 \%$} \\
\hline \multirow{4}{*}{ 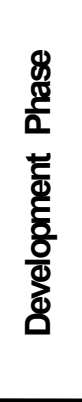 } & \multirow[t]{2}{*}{ GAMMA } & $\begin{array}{c}1 \\
\text { contract }\end{array}$ & $\begin{array}{c}2 \\
\text { contract } \\
\text { contract }\end{array}$ & $\begin{array}{c}3 \\
\text { contract } \\
\text { contract } \\
\text { contract }\end{array}$ & $\begin{array}{c}4 \\
- \\
\text { contract } \\
\text { contract } \\
\text { contract }\end{array}$ & $\begin{array}{c}1 \\
\text { expand }\end{array}$ & $\begin{array}{c}2 \\
\text { expand } \\
\text { expand }\end{array}$ & $\begin{array}{c}3 \\
\text { expand } \\
\text { expand } \\
\text { wait }\end{array}$ & $\begin{array}{c}4 \\
\text { expand } \\
\text { expand } \\
\text { expand } \\
\text { wait }\end{array}$ & $\begin{array}{c}1 \\
\text { expand }\end{array}$ & $\begin{array}{c}2 \\
\text { expand } \\
\text { contract }\end{array}$ & $\begin{array}{c}3 \\
\text { expand } \\
\text { contract } \\
\text { contract }\end{array}$ & $\begin{array}{c}4 \\
\text { expand } \\
\text { expand } \\
\text { contract } \\
\text { contract }\end{array}$ \\
\hline & & \multicolumn{4}{|c|}{ Option Value in \% PV1 = $35 \%$} & \multicolumn{4}{|c|}{ Option Value in \% PV1 = $16 \%$} & \multicolumn{4}{|c|}{ Option Value in \% PV1 = $43 \%$} \\
\hline & \multirow[t]{2}{*}{ DETA } & $\begin{array}{c}1 \\
\text { contract }\end{array}$ & $\begin{array}{c}2 \\
\text { contract } \\
\text { contract }\end{array}$ & $\begin{array}{c}3 \\
- \\
\text { contract } \\
\text { contract }\end{array}$ & $\begin{array}{c}4 \\
- \\
- \\
\text { contract } \\
\text { contract }\end{array}$ & $\begin{array}{c}1 \\
\text { expand }\end{array}$ & $\begin{array}{l}2 \\
\text { expand } \\
\text { wait }\end{array}$ & $\begin{array}{c}3 \\
\text { expand } \\
\text { expand } \\
\text { wait }\end{array}$ & $\begin{array}{c}4 \\
\text { expand } \\
\text { expand } \\
\text { wait } \\
\text { wait } \\
\end{array}$ & $\begin{array}{c}1 \\
\text { wait }\end{array}$ & $\begin{array}{c}2 \\
\text { expand } \\
\text { contract }\end{array}$ & $\begin{array}{c}3 \\
\text { expand } \\
\text { wait } \\
\text { abandon }\end{array}$ & $\begin{array}{c}4 \\
\text { expand } \\
\text { expand } \\
\text { contract } \\
\text { abandon }\end{array}$ \\
\hline & & Option & Value in & १\% PV1 & $=16 \%$ & Option & Value ir & $\%$ PV1 & $=6 \%$ & Option & /alue in ${ }^{\circ}$ & $\% \mathrm{PV} 1=$ & $16 \%$ \\
\hline \multirow{2}{*}{ 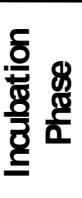 } & \multirow[t]{2}{*}{ EPSILON } & $\begin{array}{c}1 \\
\text { contract }\end{array}$ & $\begin{array}{c}2 \\
\text { contract } \\
\text { contract }\end{array}$ & $\begin{array}{c}3 \\
- \\
\text { contract } \\
\text { contract }\end{array}$ & $\begin{array}{c}4 \\
- \\
- \\
\text { contract } \\
\text { contract }\end{array}$ & $\begin{array}{c}1 \\
\text { wait }\end{array}$ & $\begin{array}{l}2 \\
\text { expand } \\
\text { wait }\end{array}$ & $\begin{array}{c}3 \\
\text { expand } \\
\text { wait } \\
\text { wait }\end{array}$ & $\begin{array}{c}4 \\
\text { expand } \\
\text { expand } \\
\text { wait } \\
\text { wait } \\
\end{array}$ & $\begin{array}{c}1 \\
\text { wait }\end{array}$ & $\begin{array}{c}2 \\
\text { wait } \\
\text { contract }\end{array}$ & $\begin{array}{c}3 \\
\text { expand } \\
\text { contract } \\
\text { contract }\end{array}$ & $\begin{array}{c}4 \\
\text { expand } \\
\text { expand } \\
\text { contract } \\
\text { abandon }\end{array}$ \\
\hline & & Optior & Value in & ר PV1 & $=13 \%$ & Optior & Value it & $\%$ PV1 & $=0 \%$ & Optic & Value in & $\%$ PV1 = & $10 \%$ \\
\hline
\end{tabular}

Figure 7. Value and flexibility of an exemplary portfolio of R\&D Venture options for a 5-year time line

The options presented in Table 4 show significant value This allows management to react to different situations that occur with the most flexibility and value for the company as a technology project is developed.

Advantageous for early stage R\&D Ventures is the flexibility to learn in the product development phase for company internal applications. When a product enjoys success, the risk of scaling into external markets is reduced. Figure 8 shows the decision tree for Epsilon. With its long development phase and reasonable R\&D efforts, Epsilon is a valid example that early learning is beneficial, significantly increases the project value, and would allow R\&D to start such a project. 


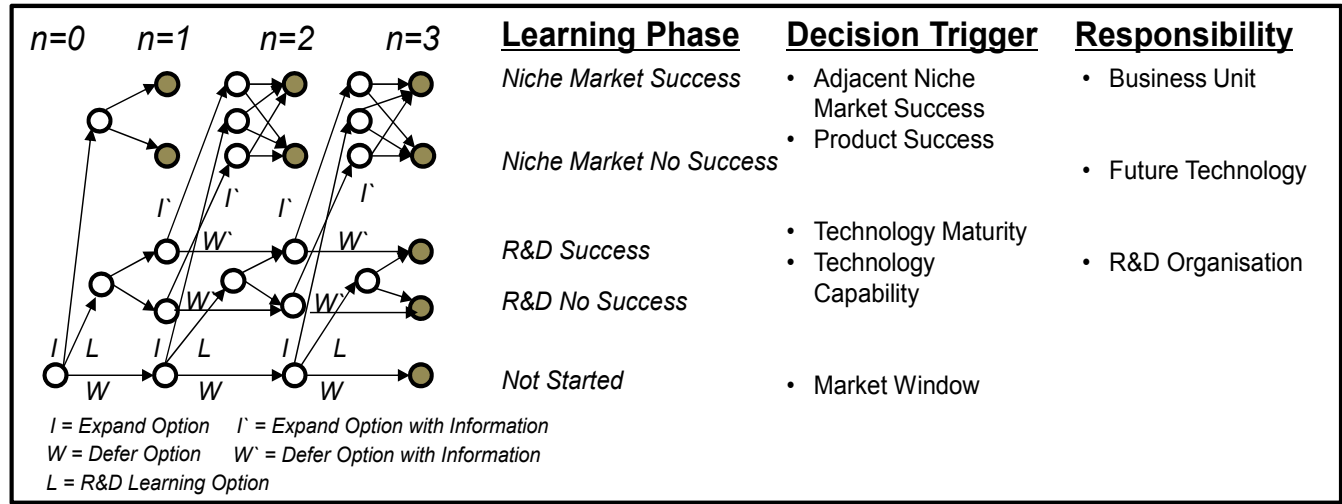

Figure 8. Decision trees for Epsilon and ROA for the learning phase adapted from Guthrie (2009)

At state zero, similar to a typical investor, the manager has the option to expand immediately. However, the options to learn by starting an internal R\&D project first or to wait are valid. For breakthrough technologies, the risk of acting as an investor and expanding into the external market immediately is high, because the uncertainty of reaching the stage of technology demonstration is significant. The learning option allows for testing the technology and developing and industrializing products for the internal applications before making major investments. The decision to start an internal R\&D project, which is made by the FTO and the R\&D organization, is triggered by the perception of technology interest, maturity, and technology capability.

The industrial partner starting an R\&D project with a venture retains the right to invest and scale the venture to external markets at a later time. Figure 9 shows the results of the learning option analysis for Epsilon. The scenario shown allows the managers to learn and gain information over a period of three years before major investments are made. The presented scenario for Epsilon results in a learning option value of up to $87 \%$ of the project's present value.

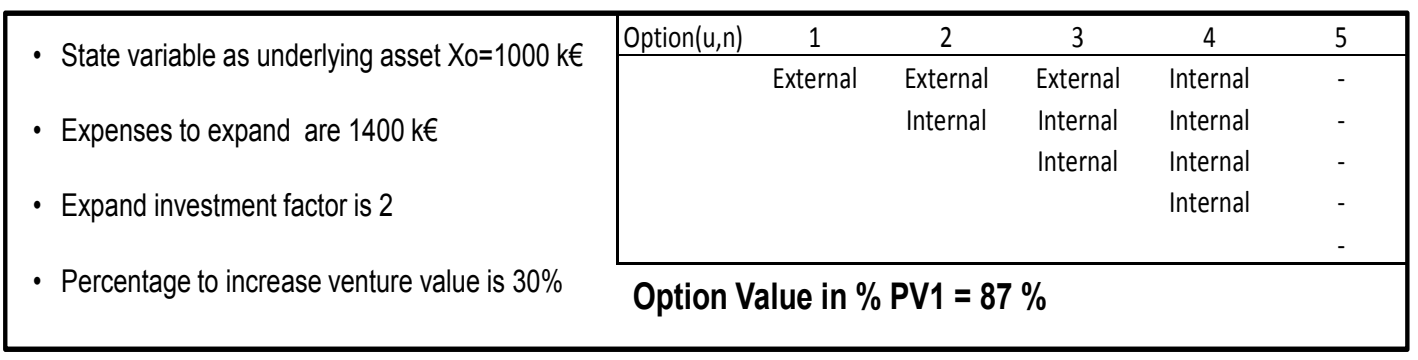

Figure 9.Value and flexibility for Epsilon's learning option and 5-year timeline

\section{FTO Model}

The open innovation discussion with ROA for the portfolio of R\&D Ventures shows that different options have different decision trigger and responsibilities; these build the basis for the FTO model proposed. ROA can be applied when the options are exogenous to the investor, and there is a limited degree of freedom to take steps to make the investment more attractive (Adner \& Levinthal 2002). Internal R\&D projects are managed by a project manager who is incentivized to achieve project targets successfully and who is inherently averse to risk of failure, which is high for breakthrough technologies. Choosing not to abandon the option in case of failure is therefore highly risky and may lead to endogenous firm decisions (Adner \& Levinthal 2002). In this case, applying real options for internal R\&D projects is severely limited. Concerning the R\&D Venture, this limitation is reduced when decisions about the option for the R\&D project are treated separately. Therefore conceptualizing the findings from above, Figure 10 summarizes the FTO model for open innovation with R\&D Ventures and suggests a separation of option decisions and organizational responsibility. The four decision-makers must independently subscribe to the R\&D Ventures business case and are commonly responsible for the option decision. Processes and capabilities support the roles and responsibilities of each unit. Corporate research, with technology expertise screens and evaluates breakthrough technologies executing the options to defer and learn. 


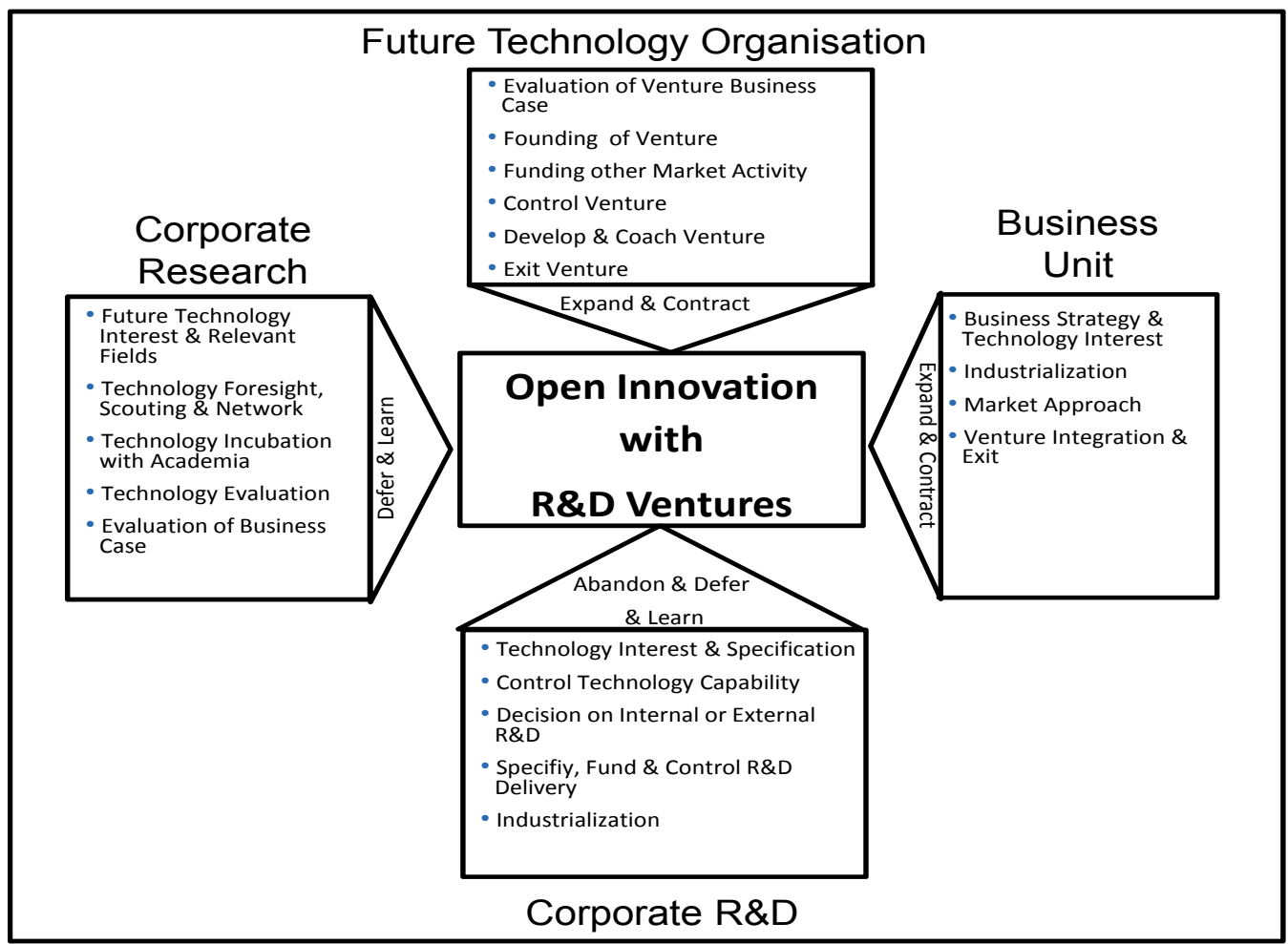

Figure 10. Open innovation with separation of option decision and organization

Corporate $R \& D$ defines the technology interest and $R \& D$ project specifications. $R \& D$ also decides on internal or external R\&D and interacts with the ventures in the R\&D project. In doing so, it executes options to abandon or defer the project and the learning options with a staged learning and a staged investment. FTO controls the expand and contract options and is responsible for the R\&D Venture business case, and for founding, controlling, developing, and finally exiting the R\&D Venture.

Finally, the business unit defines the strategic technology interest and supports industrialization and the market approach. The business unit also has the right to propose an internal exit scenario with or without venture integration, according to the R\&D Venture business case. Thus, the increased flexibility with R\&D Ventures can be realized, allowing a real option approach for the project. In such an open innovation set up the FTO is in the center position to evaluate the risks and coordinate the different organizational interests.

With the risky nature of early lifecycle technologies discussed, the FTO decision process for R\&D Ventures needs to control higher risks than in the established R\&D organization. In order to embed and operationalize the FTO model practically, FTO needs to build capabilities that will widen not only its technology acumen but also its know-how as an investor. The process of developing a technology in an open innovation approach with R\&D Ventures begins with usual technology foresight, but then new capabilities to develop and establish the venture are needed. The FTO goes on to develop the R\&D Venture until its exit.

The FTO model needs to consider a process interfacing with many internal and external partners. The FTO will manage the network and provide support with process capability; these include:

- Undertaking a financial real option evaluation of the potential R\&D Venture business case,

- Founding the R\&D Venture according to the legal rules of the company,

- Developing the R\&D Venture according business case with real option assumptions and support R\&D Venture Management,

- Finally ensuring the efficient process exit of the R\&D Venture and managing the expand or contract options.

Figure 11 illustrates the functional diagram of the FTO organizational model managing R\&D alliances in an open innovation approach with R\&D Ventures along a technology development process. It also shows the operationalization of the FTO, the real options or flexibility management and its embedded position in the open 
innovation process. The process begins with the incubation phase, in which academia, spin-offs, and inventors cooperate with the FTO to incubate the technology and develop and eventually found an R\&D Venture. Hence the development of a business case evaluating the different real options is essential.

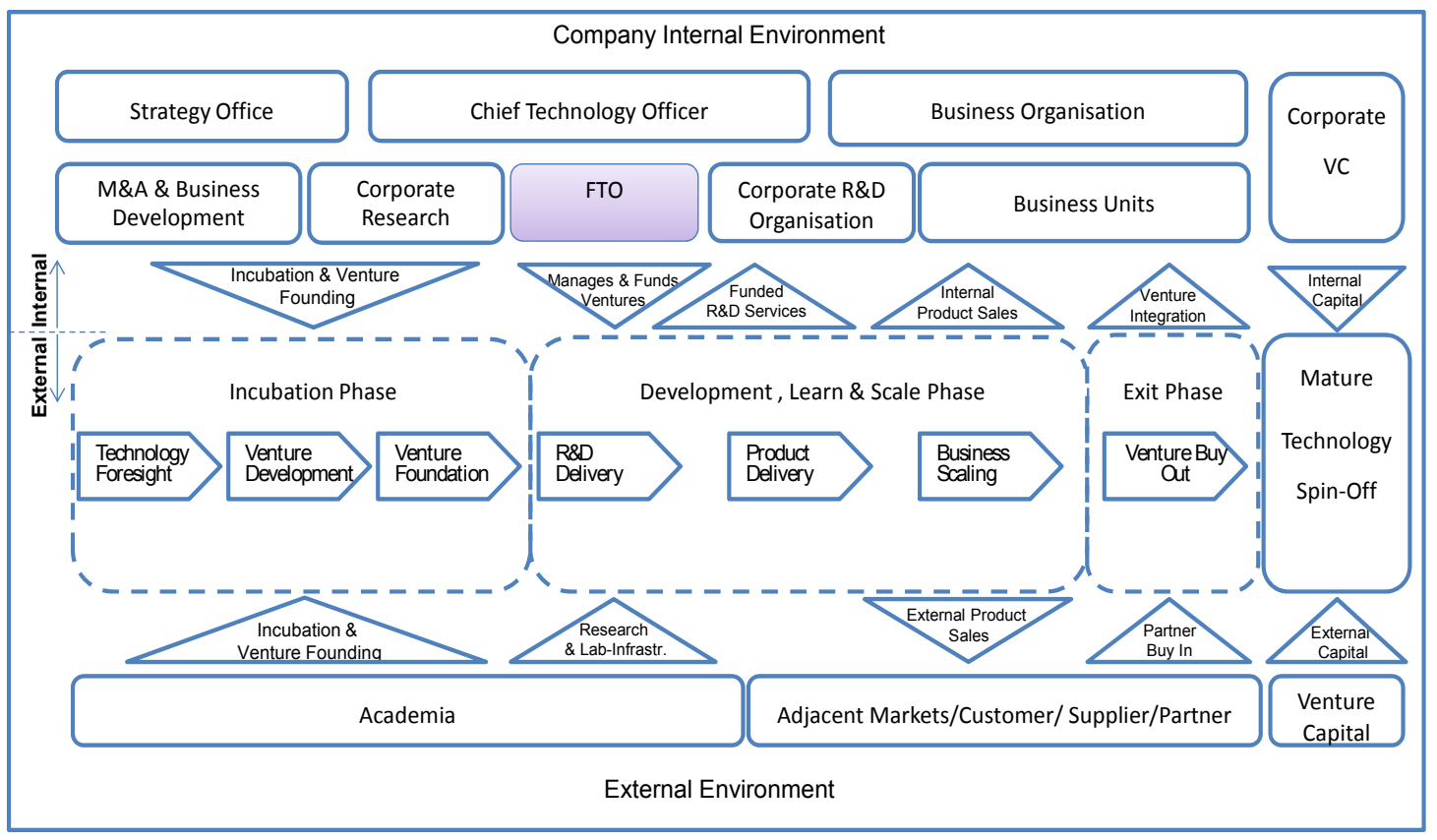

Figure 11. FTO Model; Coupled open innovation with R\&D Venture development interacting internal and external

After the R\&D Venture has been founded, it enters its development phase, which academia supports with research and the laboratory infrastructure, while the R\&D Venture in a coupled open innovation process executes and delivers R\&D services funded by the industry. Both the R\&D Venture and industry R\&D define common technology development targets and plan R\&D delivery, industrialization, field testing, and product delivery. Achieving the first industrialized products, the R\&D Venture supplies products to the industrial business unit and actively explores external markets, according to the commonly developed business plan based on real options. In this phase FTO will particular need to manage the learning, defer and abandon option.

While establishing its business, the R\&D Venture scales its production and market capabilities. Depending on the size of the R\&D Venture business, its acquisition from the industry partner and integrating it into an internal business unit might be of interest. As an alternative to the acquisition, at this stage, an external partner can be evaluated if the scaling opportunity exceeds the industry partner's interest and willingness to invest further. If the business case reveals attractive performance in other markets, the industry partner might continue to invest, and the venture can be turned into a technology and product supplier. The "buy-out", either to corporate, external venture capitalists, other industry partners, or to the R\&D Venture management is an opportunity for the industry partner as an investor. In this phase FTO needs to manage the flexibility with focus on expand and contract options.

\section{Discussion and conclusion}

The power industry is currently challenged by a time of high innovation dynamics and environmental uncertainties (Verdu et al., 2012) with many early-lifecycle technologies evolving and competing (Schilling \& Esmundo, 2009; Mowery et al., 2010). Aggressive demands for new power technologies require breakthrough innovation. Firms in this industry need to actively increase their technology and their environmental scanning behavior toward the early technology lifecycle (Christensen, 2003).

This study analyzes the risks of internal R\&D project and R\&D Venture (Hess \& Siegwart, 2013) breakthrough developments with ROA and shows the value of the options and project flexibility. The comparison shows that ROA for internal R\&D projects is limited and open innovation with R\&D Ventures allows a higher number of effective options, particularly at a later, risky stage of the process. It supports that the values of the project and risk management flexibility are increased "...ROA approaches emphasize the upside profit creating opportunities associated with uncertainty and risk." (Leiblein, p.952, 2003). This is consistent with the risky nature of early lifecycle technologies (Vanhaverbeke et al., 2008). 
In opposite to the common view that risks increase when open innovation (Chesbrough, 2003) is applied for external development of a breakthrough technology (Vanhaverbeke et al., 2008), this study shows that the risks and uncertainties can be controlled when applying a coupled open innovation process (Enkel et al. 2009) with the proposed FTO model and the R\&D Venture approach with its increased flexibility and additional options.

Open innovation and the application of real options frameworks (Copeland \& Tufano, 2004; Guthrie, 2009) for the portfolio of R\&D Ventures allows businesses to evaluate and compare the risk exposure of a technology development approach with internal or external capabilities and resources, which is supported by the open innovation literature (Lo Nigro et al., 2013). However Dahlander \& Gann (2010) found that there is a limited understanding about the cost of openness, the underlying decision process and the elaboration of "...open innovation from the perspective of product/ technology lifecycles and the different phases through which an innovation evolves from conceptualization to commercialization." (Dahlander \& Gann, p.707, 2010). The discussed analyses of the options to abandon, defer, expand, or learn of this study aims to allow for calculating a project's risk profile in financial terms (Benninga \& Tolkowsky, 2002), highlights the decision process and introduces a technology perspective along the early lifecycle of a product/ technology. The discussion with decision trees along the technology process stages shows that different options have different decision trigger and responsibilities (Dahlander \& Gann, 2010). These define the FTO Model derived to control and mitigate risk with breakthrough technologies. In this context particular the learning option is of high value (Yeo \& Qiu, 2002; McDonald \& Siegel, 1986), it allows to shift a joint venture or alliance to a “...more hierarchical form of governance in response to the receipt of positive information." (Leiblein, p.953, 2003).

Adner \& Levinthal (2002) argued that there are limits applying the ROA method to a technology innovation project; the project must be conform to the structure of a real option, which is separate or exogenous from the investor. The FTO model proposed, which is established with four decision-making and option-responsible units, commonly aims realizing the evaluated flexibilities and the development of the $R \& D$ Venture.

In the model presented the FTO acts as a company's internal technology foresight organization, responsible for external technology scouting, screening and posting (Reger, 2010) - that is, as a company's internal agent of technology (Gassmann \& Gaso, 2004). However applying open innovation and ROA this study shows that the FTO also needs to develop investor acumen and the capability to manage a central network position with many internal and external interfaces along the open innovation process.

This study has been based on case studies. Hence conclusions must be drawn with care. Generalizations made from what may be unique patterns can be misleading and should be supported by the knowledge and insight of the cases discussed. The extent to which the presented proposals and frameworks can be generalized depends on how well early-stage innovation can be explained in other settings.

Factors which may restrict and impact the effectiveness and efficiency of the proposed methodology are naturally manifold. On the industry and venture side, these include unclear processes and organization, their unfavorable implementation, over-aggressive financial expectations, high levels of management fluctuation, lack of incentive, and strong "Not Invented Here Effects" (Katz \& Allen, 1982) - all of these can impact the proposed approach negatively.

However, the author believes that future research, which investigates the appropriate alliance timing, portfolio dynamics and value contribution of an R\&D Venture group for breakthrough technologies and their exit scenarios, will reveal a large field of innovation opportunities, which are of considerable socio-economic value. The author would also like to emphasize that a real option investigation, as for R\&D Ventures, would be relevant for ventures portfolio, targeted to reducing the risk of breakthrough technology development.

\section{References}

Adams, J. D. (2005). Industrial R\&D Laboratories: Windows on Black Boxes? Journal of Technology Transfer, 30 $1 / 2,129-137$.

Adner, R., Levinthal, D. (2002). What is not a real option: Identifying Boundaries for the Application of Real Options to Business Strategy. Fontainebleau, France: Working Papers, INSEAD.

Ahuja, G., Lampert, C. M. (2001). Entrepreneurship in the large corporation: a longitudinal study of how established firms create breakthrough inventions. Strategic Management Journal, 22: 521-543. http://dx.doi.org/10.1002/smj.176.

Andersson, M., Lööf, H. (2011). Small business innovation: firm level evidence from Sweden. Journal of Technology Transfer. http://dx.doi.org/10.1007/s10961-011-9216-9. 
Arvanitis, S., Kubli, U., Sydow, N., Wörter, M. (2005). Knowledge and Technology Transfer Activities Between Universities and Firms in Switzerland. Facts: An Empirical Analysis Based on Firm-level Data, Zürich: ETH Konjunkturforschungsstelle, Report.

Benninga, S., Tolkowsky, E. (2002). Real Options - An Introduction and an Application to R\&D Valuation. The Engineering Economist, Vol. 47, No. 2, 151-168, http://dx.doi.org/10.1080/00137910208965030.

Black, F., Scholes, M. (1973). The pricing of options and corporate liabilities. Journal of Political Economy, 81, 637-659. http://dx.doi.org/10.1086/260062

Chesbrough, H. (2003). Open Innovation. The New Imperative for Creating and Profiting from Technology. Boston Massachusetts: Harvard Business Review Press.

Chesbrough, H., Vanhaverbeke, W., West, J. (2006). Open Innovation. Researching a New Paradigm. New York: Oxford University Press.

Christensen, C. M. (2003) The Innovator's Dilemma. New York: Harper Business Essentials Edition.

Cohen, W. M., Levinthal, D. A. (1989). Innovation and Learning: The Two Faces of R\&D. The Economic Journal, Vol. 99, No. 397 (September), 569-596. http://dx.doi.org/10.2307/2233763

Copeland, T., Antikarov, V. (2001). Real Options. A Practitioner's Guide. New York: Texere.

Copeland, T., Tufano, P. (2004). A Real-World Way to Manage Real Options. Harvard Business Review, March, 1-11

Dahlander,L., Gann, M.G. (2010). How open is innovation? Research Policy, 39, 699-709. http://dx.doi.org/10.1016/j.respol.2010.01.013

Eisenhardt, K. M., Graebner, M. E. (2007). Theory Building From Cases: Opportunities and Challenges. Academy of Management Journal, Vol. 50, No.1, 25-32. http://dx.doi.org/10.5465/AMJ.2007.24160888

Enkel, E., Gassmann, O., Chesbrough, H. (2009). Open R\&D and open innovation: exploring the phenomenon. $R \& D$ Management, 39, 4, 311-316. http://dx.doi.org/10.1111/j.1467-9310.2009.00570.x

Fontes, M. (2005). The process of transformation of scientific and technological knowledge into economic value $\begin{array}{lllll}\text { conducted by biotechnology } & \text { spin-offs. }\end{array}$ http://dx.doi.org/10.1016/j.technovation.2003.08.004.

Flick, U. (2002). An Introduction to Qualitative Research. London: SAGE Publications.

Gassmann, O., Gaso, B. (2004). Insourcing Creativity with Listening Posts in Decentralized Firms. Creativity and Innovation Management, Vol. 13, No.1 (March), 3-14. http://dx.doi.org/10.1111/j.1467-8691.2004.00289.x

Gilbert, C. G. (2005). Unbundling the structure of inertia: resource versus routine rigidity. Academy of Management Journal, Vol. 48, No. 5 (October), 741-763. http://dx.doi.org/10.5465/AMJ.2005.18803920

Guthrie, G. (2009). Real Options in Theory and Practice. New York: Oxford University Press.

Harhoff, D., Licht, G. et al. (1996). Innovationsaktivitäten kleiner und mittlerer Unternehmen. Ergebnisse des Mannheimer Innovationspanels. Baden Baden: Nomos Verlagsgesellschaft.

Henderson, R. (1993). Underinvestment and Incompetence as Responses to Radical Innovation: Evidence from the Photolithographic Alignment Equipment Industry. The RAND Journal of Economics, Vol. 24, No. 2 (Summer), 248-270. http://dx.doi.org/10.2307/2555761

Hess, S., Siegwart, R. Y. (2012). R\&D Venture: proposition of a technology transfer concept for breakthrough technologies with R\&D cooperation: A case study in the energy sector. Journal of Technology Transfer, 38, 153-179. http://dx.doi.org/10.1007/s10961-012-9249-8.

Hess, S., Siegwart, R. Y. (2013). University Technology Incubator: technology Transfer of Early Stage Technologies in Cross-Border Collaboration with Industry, Business and Management Research, Vol 2, Nr. 2, 22-36

Hess, S., Suhrbeer S., Siegwart, R. Y. (2013). The Impact of Collaboration Innovation between Established Industry and Academic Technology Spin-Offs, Business and Management Research, Vol. 2, Nr. 3, 1-15.

Kanter, R. (1985). Supporting innovation and venture development in established companies. Journal of Business Venturing, 1, 47-60. http://dx.doi.org/10.1016/0883-9026(85)90006-0

Katz, R., Allen, T. J. (1982). Investigating the Not Invented Here (NIH) syndrome: A look at the performance, tenure, and communication patterns of 50 R\&D Project Groups. R\&D Management, 12, 1, 7-19. http://dx.doi.org/10.1111/j.1467-9310.1982.tb00478.x 
Leiblein, M. J. (2003). The Choice of Organizational Governance Form and Performance: Predictions from Transaction Cpst, Resource-based, and Real Option Theories, Journal of Management, 29(6), 937-961. $\mathrm{http}: / / \mathrm{dx}$.doi.org/10.1016/S0149-2063(03)00085-0

Lo Nigro, G., Moreale A., Enea, G. (2013). Open Innovation: A real option to restore value to the biopharmaceutical R\&D, International Journal of Production Economics. http://dx.doi.org/10.1016/j.ijpe.2013.02.004

Miles, M. B., Huberman, A. M. (1994). Qualitative Data Analysis. Sage Publications.

Marmer, M., Herrmann, B. L., Berman, R. (2011). Startup Genome Report 01. A new framework for understanding why startups succeed. Stanford University Report, May.

McDonald, R., Siegel, D. (1985). Investment and the valuation of firms when there is an option to shut down, International Economic Review, 26, 2, 331-349. http://dx.doi.org/10.2307/2526587

McDonald, R., Siegel, D. (1986). The value of waiting to invest. Quarterly Journal of Economics, 101, 4, 707-727. http://dx.doi.org/10.2307/1884175

Mowery, D. C., Nelson, R. R., Martin, B. R. (2010). Technology policy and global warming: Why new policy models are needed (or why putting new wine in old bottles won't work). Research Policy, 39, 1011-1023. http://dx.doi.org/10.1016/j.respol.2010.05.008.

Papart, G. (2004). The case for strategic partnering between science and industry in Europe, Special Conference, "Partnering between Science and Industry. Effective Collaboration R\&D and Knowledge Transfeer", Bruxelles, 5-6 February, 2004

Patton, M. Q. (2002). Qualitative Research and Evaluation Methods. Thousand Oaks, California: Sage Publications.

Perlitz, M., Peske, T., Schrank, R. (1999). Real Options valuation: the new frontier in R\&D project evaluation?, $R \& D$ Management, 29, 3, 255-269. http://dx.doi.org/10.1111/1467-9310.00135

Polt, W., Rammer, C., Schartinger, D., Gassler, H., Schibany, A. (2001). Benchmarking Industry-Science Relations in Europe - the Role of Framework Conditions. Science and Public Policy, Vol. 28, No. 4 (August), 247-258. http://dx.doi.org/10.3152/147154301781781453

Reger, G. (2010). Technology Foresight in Companies: From an Indicator to a Network and Process Perspective. Technology Analysis \& Strategic Management, Vol.13, No. 4, 533-553, http://dx.doi.org/10.1080/0953732012009543 7.

Rohrbeck, R. (2007). Technology Scouting - a case study on the Deutsche Telekom Laboratories. ISPIM-Asia Conference; New Delhi, India.

Schilling, M. A., Esmundo, M. (2009). Technology S-curves in renewable energy alternatives: Analysis and implications for industry and government. Energy Policy, 37, 1767-1781, http://dx.doi.org/10.1016/j.enpol.2009.01.004.

Stankiewicz, R. (1994). Spin-off companies from universities. Science and Public Policy, 21(2), 99-107. http://dx.doi.org/10.1093/spp/21.2.99.

Tornatzky, L. G., Fleischer, M. (1990). The Processes of Technological Innovation. Massachusetts / Toronto: Lexington Books.

Utterback, J. M., Abernathy, W. J. (1975). A Dynamic Model of Process and Product Innovation. OMEGA, The International Journal of Management and Science, Vol. 3, No. 6, 639-656.

Vanhaverbeke, W., Van de Vrande, V., Chesbrough, H. (2008). Understanding the Advantages of Open Innovation Practices in Corporate Venturing in Terms of Real Options. Creativity and Innovation Management, Vol. 17, No. 4, 251-257. http://dx.doi.org/10.1111/j.1467-8691.2008.00499.x.10

Verdu, A.j., Tamayo, I., Ruiz-Moreno, A. (2012). The moderating effect of environmental uncertainty on the relationship between real options and technological innovation in high-tech firms, Technovation, 32, 579-590. http://dx.doi.org/10.1016/j.technovation.2012.06.001

Yeo, K.T., Qiu, F. (2002). The value of management flexibility - a real option approach to investment evaluation, International Journal of Project Management, 21, 243-250. http://dx.doi.org/10.1016/S0263-7863(02)00025-X

Yin, R. K. (2009). Case Study Research. Design and Methods. Fourth Edition. Thousand Oaks, California: Sage Publications. 